\title{
Not Compounding Sterile Product
}

National Cancer Institute

\section{Source}

National Cancer Institute. Not Compounding Sterile Product. NCI Thesaurus. Code C112095.

A compounder does not produce a sterile product. 